\title{
THE CONCEPT OF AGENCY THEORY IN ELECTORAL DEMOCRACY
}

\author{
Joseph Kwaku Asamoah
}

Joseph Asamoah is the Director of Finance,

Electoral Commission of Ghana, Electoral Commission of Ghana, Accra

\begin{abstract}
This essay analyses the doctrine of the law of agency in the context of electoral democracy in assessing the rights and liabilities of the political elite and the voting public. The principal-agent model was employed to expatiate challenges in the relationship between the agent's performance and how the principal can reward or punish the agent through competitive elections. In doing so, the elected political authorities are deemed to be agents of state governance while the voters, and by extension the population, are seen as principals of the state. The principal-agent relationship generates the electoral accountability of representatives to constituents by checking and controlling the behaviour of the political elite to ensure that national programmes, policies and laws are applied for the benefit of the general public. The study concludes that voters, as principals, expect political agents to deliver public goods and services to their benefit and that failure do so attracts a vote of censure. This means that competitive elections create a relationship of formal accountability between political leaders and voters. This accountability minimises the ability of political leaders to use the advantage of information asymmetery.
\end{abstract}

Keywords: principal-agent theory, agency cost, electoral agency theory, moral hazard, adverse selection, public accountability

\section{INTRODUCTION}

The doctrine of agency has been widely expounded in different academic fields. In recent years various economic and political scholars have applied the doctrine of the principal-agent relationship to the study of the nexus between the elected and the electorate (Hammond \& Knott 1996; Weingast \& Moran 1983). A study by Bratton and Logan (2014), avers that 84 percent of the voting public in several African countries associate themselves with free and fair elections - 
including Tunisia, South Africa, Ghana, Senegal and Algeria, Nigeria, Lesotho and Botswana, where there is indisputable support for competitive elections as the instrument for electing leaders. Competitive elections create a relationship of direct accountability between citizens and the organs of state. An important contribution to this concept was made by Ferejohn (1986), who assumed a situation of moral hazard between voters and the government. He posits that government can improve the outcome for voters by executing its mandate in the interests of the voter. According to Ferejohn, voters could in turn commit to a retrospective voting strategy by voting the government out should its performance fall below expectations. These electoral rewards and punishments are realised on election day.

A useful analysis of the test of accountability between elected and electorate is the theory of political agency, which elucidates the incentives provided by elections. The rational choice theory of political agency perceives agents as decision makers with the capacity for rational choices to pursue the interests of their principals (Downs, 1957). From that perspective, all citizens might be regarded as principals whose interest political agents must pursue. Other theorists, particularly those inspired by Immanuel Kant, focus on moral agency, that individuals be held accountable for their acts and are capable of assuming duties with rights. This exercise of accountability requires the voter to make decisions in an atmosphere of autonomy and freedom with the reflective capacity to guide such decisions.

This theoretical framework asserts that incentives are driven by the incumbent government in an effort to impress the voters, and this desire often conflicts with the commanding authority, that is the obligation to advance the interest of the voters rather than pursue policies of self-interest. The incumbent's electoral incentives to act within or contrary to the voters' interests is guided by the voters' decision to act rationally in all electoral cycles. Aidt and Magris (2003) postulate that the dynamic incentives provided by retrospective voting can partially solve the problem of 'capital levy'. At the core of democratic governance is the expectation that citizens can compel public officials to be responsive to issues of government policies, public expenditure, and popular needs of the people (Moncrieffe 1998; Goetz \& Gaventa 2001). This is also supported by Besley and Burgess's (2002) use of the incentive model to generate workable predictions about the determinants of government responsiveness in providing public good to the citizens. For example, after the adoption of the 1992 Constitution, the political system of Ghana took place in a framework of a presidential, representative democratic republic (Crawford 2004). The political system after 1992 was a blend of both the parliamentary and presidential systems. Article 42 of the 1992 Constitution provides that every citizen of Ghana who is eighteen years of age 
or above and of sound mind has the right to vote and is entitled to be registered as a voter for the purposes of public elections and referenda in elections that take place every four years. Since its return to multi-party democracy in 1992, Ghana has had seven successive elections which have seen power alternating from incumbent to opposition.

Voters in turn do not always look at performance during the course electoral cycles. As electoral competition has come of age with several decades' worth of electoral events, voters sometimes vote on an ideological basis and/or a political track record, and not just the current crop of politicians and programmes. Voters are often unwilling to be carried away by self-serving politicians in exchange for hollow promises, and thus the debate among voters in some African economies focuses on politicians' performance, track-records, and citizens' own expectations and aspirations. These factors inform the voter's choice in elections; however, this may be defeated during elections by political coalitions and ideologies. For example, in South Africa the continued hegemony of the African National Congress (ANC) since 1994 allows the party to short-circuit their electoral accountability to the citizens, which may presage the need for political coalitions by opposition parties to reduce the electoral preference for ANC.

Every five years the South African electorate has the opportunity to hold government to account for its past performance in office. South Africa has held five successful national and provincial democratic elections since 1994 which have seen the electoral dominance of the governing ANC. While voters in Ghana may have the opportunity to hold political leaders accountable through competitive elections, their counterparts in South Africa have a lesser level of accountability due to the historically predictable outcome of elections. The electoral imbalances in the party system and the static and predictable nature of voting outcomes have raised concerns that elections fail to hold politicians to account.

For elections to act as an effective accountability tool, voters must be willing to sanction incumbents by looking at their past performance and punishing poor governance by revoking their support at the polls. O'Donnell (1994) posits that competitive elections provide citizens with periodic opportunities to reward or punish incumbent leaders. According to Sean (2012), elections have been identified as the main tool for getting politicians to act in the interests of voters. Elections allow citizens to hold their leaders accountable even in infant democracies. This provides a direct agency relationship between the voters and the elected government with the voters acting in the capacity of principal while the executive and legislative arm of government acts in the representative capacity of an agent. This amounts to bestowing public accountability on the agent (government) to act at all material times in the best interests of the principal (voters).

For example, Nigeria, the most populous country in Africa with the largest economy, runs a four-year electoral cycle which gives voters the opportunity 
to hold political office-bearers accountable. As Nigeria goes to the poll in 2019, voters will use the election as a referendum on the president, governors and all federal and state legislators. Similarly, Botswana has an uninterrupted history of competitive elections since 1965, and voters hold political leaders to account every five years.

However, incentives provided by elections could be driven by the agent's desire to impress the voters, and this desire often conflicts with the imperative to advance the interests of the voter, endorsing the demand and supply theory of Rose et al (1998). This theory is used to differentiate popular demand for political goods from the supply of such goods produced by the political authority. The political authority may seek to maximise its own freedom motivated by the drive to occupy political office, and in so doing may insulate itself from excessive popular claims. In pursuit of their own political agenda, incumbent leaders find advantage in managing mass demands and limiting the amount of accountability they are willing to supply. As a result, the electorates can demand accountability by making political leaders answer for their official conduct. However, this demand by voters is effective only to the extent that information on government programmes, policies and performance can be accessed freely through political offices, mass media and social media. This in turn casts some doubt on the rational choice theory of the voter. According to Ashworth (2012), the political authority's electoral incentives to act contrary to voters' interests might arise even if all voters act perfectly rationally. This means that rational voters can create bad incentives especially in an ethnically obsessed political economy which does allow for proportional representation. Voter's choices during competitive elections in those economies may not be based on whether or not the incumbent government performs in the interest of the citizens; rather, that choice may be influenced by ethnic and partisan ideologies. For example, in Kenya, the ethnic, social and political fragmentation between the Kikuyus and Kalenjins has been consciously manipulated by the political elite during elections which invariably reduce discussions to bread and butter issues. In contrast the implementation of the list system of proportional representation in South Africa has promoted inclusivity by opening up the elections to a number of parties, allowing them to vie for some degree of representation for different ethnic and other concerns. Although this system may dilute the accountability threshold of the political authority, it may nonetheless foster national cohesion and inclusiveness.

Voters can decide to vote either for or against an incumbent political authority, at least potentially on the basis of political ideology, affiliation and/or ethnicity. This is regardless of whether or not the incumbent or the incoming administration performs in the interest of the voters. 
Public accountability is a function of the capabilities of principals to pass judgement on the performance of their agents (Achen \& Bartels 2002; Healy \& Malhotra 2010; Lenz 2012; Lupia \& McCubbins 1998). The accountability view of elections therefore suggests that elections serve to hold governments responsible for the results of their past actions. Because they anticipate the judgment of voters, governments are induced to choose policies that in their judgment will be positively evaluated by citizens at the time of the next election (Afrobarometer Round 2,2002). This calls on an incumbent government to prioritise policies and programmes aimed at boosting and meeting the legitimate interests of the voters. To make sense of the relationship, the government must establish accountable institutional structures to function in the interest of the voter. However, the agency problem arises in many situations in sub-Saharan Africa where governments, once elected, begin to implement policies and programmes that are inimical to voters' interests. Although most literature on agency is in the context of industrial economics, the concept has substantial implications for the study of electoral

politics. Consequently, this article seeks to explore the principal-agent theory which has become a widely-used model for analysing public accountability. This is largely because it provides a flexible framework for modelling the performance variations in the competencies of various political parties and their candidates, thereby affording voters the opportunity to compare their potential for inducing desirable behaviour by agents.

\section{PRINCIPAL-AGENT THEORY}

In the case of The Queen $v$ Kane (1901), Lord Alverstone CJ defined an agent as 'any person who happens to act on behalf of another'. The United States Restatement of the Law of Agency (2006) defines agency as 'a fiduciary relationship that arises when one person (a principal) manifests assent to another person (an agent) acting on the principal's behalf and subject to the principal's control, and the agent manifests or otherwise consents so to act'. Agency model is considered to be one of the oldest theories in the literature of management and economics (Daily, Dalton \& Rajagopalan 2003; Wasserman 2006). Agency theory helps to implement various governance mechanisms to control the agents' action(s) in the interest of the principal. Berle and Means (1932) found that the modern organisation experience dispersed ownership, warranting the need to separate ownership from control. In a limited liability company, ownership is held by individuals or groups by virtue of share ownership and these shareholders (principals) delegate the authority to the managers (agents) to run the business on their behalf (Jensen \& Meckling 1976; Ross 1973). The major issue is whether these managers are performing in the interest of the owners or for their own interest. 
According to Sealy and Hooley (2008) there are three main theories that seek to define and explain agency. These are power-liability theory, consent theory and qualified consent theory. Firstly, according to the power-liability theory an agency exists when a person (the agent) acquires the power to alter the principal's legal relations with a third party so that only the principal and not the agent can sue or be sued by that third party. Secondly, consent theory takes a different approach to the definition of agency: according to the US Restatement (Third) of Agency (Tentative Draft No 2) (2003), agency constitutes the fiduciary relationship that arises when one person (a 'principal') manifests assent to another person (an 'agent') that the agent shall act on the principal's behalf and subject to the principal's control, and the agent manifests assent or otherwise consents to act. This deals with the criticism of the power-liability theory by focusing on the fiduciary duty owed by an agent to a principal. Finally, the qualified consent theory combines consent theory with the protection of 'misplaced reliance' to account for actual and apparent authority.

The question of agency tends to focus on the extent of the agent's authority and how this affects the principal's interest. An agent can only bind the principal if the agent has some kind of authority to do so, otherwise the principal will not be bound to the contract (Sealy \& Hooley 2008). Basically, the agent would have to express either actual authority or apparent authority in order to bind the principal. This article seeks to analyse the agency relationship between the incumbent government and the voter in respect of actual authority bestowed on the incumbent by the voter. In certain jurisdictions the nature and design of the electoral system could produce different outcomes of this formal contractual agency theory. For example, in jurisdictions where proportional representation electoral system is practised such as South Africa and Lesotho, parties gain seats in proportion to the number of votes cast for them. Agency relationships between government and voters in these countries could result in an unexpected outcome because parties might campaign individually on manifestoes but could subsequently form coalitions and alliances after the elections, thereby defeating the electoral-based contract between a particular incumbent government and the voters.

Actual (express) authority is the mandate the principal gives the agent to enter into the arrangement on the principal's behalf. The actual authority of the agent could be either expressed or implied. In the case of Aviva Life and Pensions UK Ltd v Strand Street Properties Ltd (2010), it was established that express actual authority may be contained in documents or agreements between the principal and the agent detailing the express instructions within which the agent must operate. Where the agent acts in excess of actual authority, the principal shall not be bound by that transaction. According to Article 57(1) of the 1992 Constitution 
of Ghana 'there shall be a president of the Republic of Ghana who shall be the Head of State and Head of Government and Commander-in-Chief of the Armed Forces of Ghana'. Again, through the doctrine of agency, Article 93 of this Constitution requires the election of members of parliament to represent the constituent principals. The mandate of state governance is given to the elected executive and legislative arm of government (the agents) by principals, being the voters in democratic elections through the ballot box. Note, however, that once elections produce agents, both the voters and non-voters together form citizens (the principals) in whose best interests the elected officials must serve.

This means that with regard to the actual authority of the state, the state's agents need express authorisation from the principal (the state) to execute its responsibilities. These authorisations are contained in laws enacted by the citizen's representatives (parliamentary agents). This underscores that fact that under the express authority agency theory, the elected and appointed state officials are required to perform their activities in compliance with the express dictates of the law, and that failing to do so amounts to a breach of agency relationship. A vote of censure can then apply during re-election. The theory of implied actual authority requires an agent to undertake activities that are necessary and incidental to perform task(s) within the agent's actual express authority. In state governance, this translates to those who have been elected formulating programmes, policies, cabinet decisions, institutional establishment as well as appointing heads of ministries, departments and agencies necessary for executing the mandates bestowed on the government by the voters.

This calls into question the extent of accountability between the institutions of state and the people they represent. There is thus a need to analyse and evaluate the degree of public accountability, which demands a specific structure of who is accountable to whom. This is the overarching characteristic of principal-agent theory. According to The Queen $v$ Kane (1901), in principal-agent models an agent undertakes an action on behalf of another person called the principal. In support, Sean (2012) avers that the principal can therefore make decisions that affect the incentives of the agent to take various possible actions. This process of structuring incentives for the agent is an essential ingredient of principal agent theory. Bolton and Dewatripont (2004) posit that principal-agent theory is an agreement in a form that is generally coterminous with contract theory. This makes the decision of the principal that structures the agent's incentives to take various actions constitute a binding contract between the principal and the third party, whereby non-performance on the part of the agent would constitute a breach of contract. In Montgomerie v United Kingdom Mutual Steamship Association (1891), it was established that where a person contracts as agent for a principal, the contract is that of the principal, and not that of the agent; and, prima facie, in common law the only 
person who may sue and be sued under the contract is the principal. Analogous to contractual relationships there exist rights and obligations between the agent and the principal such that a breach of agency duties can result in contractual damages. This means that principal-agent models specify a set of possible actions the parties can take, and how they evaluate consequences of those actions.

However, where an agent carries out an act in the name of a principal for which he was not authorised, the principal may decide to ratify the transaction. If the principal decides to ratify the transaction then he adopts the agent's unauthorised acts, which then become authorised ab initio. In other words, ratification is equivalent to antecedent authority and the agent will be regarded as having retrospective actual authority. In electoral agency, ratification can be described as a situation where a particular candidate or political party seeks reelection or parliamentary impeachment proceedings by an absolute majority of vote by members of parliament in the form of vote of no confidence. A motion of no confidence requires the majority of the members of parliament to vote in favour of the motion. For example, in 2017, then president of South Africa, Jacob Zuma, survived a motion of no confidence when the opposition members of parliament joined forces to censure him for various allegations of corruption.

This calls on the voters (principals) to decide whether or not to ratify the failure of the candidate to perform in their interest. In competitive elections where the incumbent is voted into power, the doctrine of agency ratification is deemed to have taken place. On the other hand, when the incumbent is voted out of power, the voter is deemed to have exercised the power of censure by declining to ratify the incumbent's unauthorised conduct, both action and inaction, making the agent liable to state governance.

Notwithstanding the above, the principal-agent theory relationship is not without fundamental challenges. These difficulties concern the relationship with moral hazard or hidden actions, and those dealing with adverse selection or hidden information. In moral hazard problems, the agent takes actions that may affect the principal's interest. This happens where the principal and agent have different preferences over the choice of possible actions the agent could take, but the principal cannot directly control the agent's action. The principal observes some information affected by or correlated with the agent's action and administers a reward or punishment, such as re-election or rejection, based on that information. In adverse selection problems, the agent is privy to some information that the principal needs in order to decide in the principal's interest, but the agent prefers such information to be used differently. This makes it difficult for the principal to directly control the actions of the agent.

The moral hazards and adverse selection difficulties arise whether the contract is explicit, as with implementation of programmes and policies, or is 
opaque and only enforceable to a limited extent, as with politics (Jan-Erik Lane 2013). Central to the analysis of both moral hazard and adverse selection problems is the compatibility of incentive. According to Rasmusen (2006), the application of the principal-agent theory in the private sector has been related to the salary of CEOs and the choice of contracts. Here the model is analysed on the principle that the principal hires the agent on the basis of a contract involving work whereby the agent is paid according to the value of the output delivered. The principal's output expectation is a function of the effort required of the agent. Since the principal aims for high output, the principal would create a contract that requires high effort from the agent. These contracts are subject to the contract meeting the expectations of the principal, that is the contract between agent and principal must meet the expectations of the principals, the voters. When it is applied to politics, the principal-agent interaction will start backwards with first, the government choice of agents to handle the provision of public services; and second, the electorate's choice of political agents with different policy preferences. However, with asymmetric information regarding hidden actions and hidden knowledge, there are suboptimal solutions. This is evident in political and bureaucratic literatures. The Niskanen model of bureaucracy with public choice provides a principal-agent model whereby the agents employ information to their advantage to deliver a suboptimal level of public service. In an undemocratic political state where power is centralised, the government monopolises politics for its own benefit in order to reduce the population to some form of political subjugation by restricting the choice of the electorate in order to systematise control.

Incentive compatibility simply means that the principal must make the agent's role worth the principal's interest. However, incentive compatibility imposes constraints on the principal. This requires the principal to trade off the benefits of improved decision from its own point of view, against the costs of inducing the agent to take that particular course of action. For example, if the agent's liability for poor performance is limited in one way or another, then in general, incentive compatibility constraints imply that the principal will not induce the agent to pursue the principal's interest, even if the principal is theoretically able to do so. Principals are therefore called upon to trade off agency loss against the cost of satisfying incentive compatibility. However, the mere existence of agency loss does not imply that the public accountability of the agent is suboptimal in the view of the principal since agency loss is not necessarily inevitable.

\section{ELECTORAL AGENCY THEORY}

Bovens (2007) defines accountability as a relationship in which an agent has an obligation to explain and justify conduct to a principal. In an electoral democracy, 
the key relationship is between voters as principals and public officials as their agents. According to Adsera and Boix (2003) accountability (referring to how well any government functions) hinges on how good citizens make their politicians accountable for their actions. Competitive elections create a relationship of public accountability between policy makers and citizens. This responsibility is handed out on election day through electoral reward and punishment. The overarching objective is that this formal public accountability should give birth to good governance. For example, the architects of the Ghanaian constitution created an institutional framework for the creation of not just democracy, but of a representative democracy where election is centripetal. This representative form of democracy through elections produces incentives and disincentives for an agent acting on behalf of a principal that he is presumed or contracted to represent. However, voting on election day alone is not enough to guarantee the assessment of incentives offered by the agents. Studies indicate that voters seem to do well in a relative performance evaluation of the economy but do less well in assessing shock factors of the economy (Besley \& Case 1995b; Kayser \& Peress 2011). This means that other variables in a competitive democratic electoral process must be in place, such as an election campaign period allowing parties, candidates and voters to interact freely and sufficiently to exchange necessary information for an informed decision by the electorate/principal. This has the potential of affording the voter a pre-election evaluative choice in selecting a particular candidate or political party, which prevents agents holding political power from putting their own interests over those of the voters. The dividend of electoral democracy is that voters can hold political officials accountable for their policy choices, and thereby ensure a close connection between the will of the public and public policy options. However, in holding the political authorities accountable, cognisance must be given to voter imperfections. Voter imperfections include the inabilities, irrationalities and lack of attention on the part of the voter to hold political officialdom accountable.

Regardless of the imperfections in voters, the question is whether state agencies such as election management bodies, the judiciary, security forces, media and civic educators are fulfilling their constitutional duties. For example, while it remains a reasonable expectation by the rational voter that the media will hold political authority to account by exercising their watchdog role, in some instances the state media is used as a propagandist vessel for the government at the expense of the voter. Again, while the role of the courts is to hold the executive legally accountable, parliaments in a democracy are empowered to command political accountability. However, these state institutions may fail to exercise their constitutional checks and balances on the political executive to the disappointment of the voter. These factors, therefore beg the question as to whether, even in 
conditions of perfect voter attention and rationality, these state agencies do limit the accountability of the voter's interest. This issue underscores the exploration of the principal-agent analyses of elections where voters are the principal(s) and politicians remain the agents (Dixit et al 1997). Studies show that a pure moralhazard concept of electoral accountability uses elections as instruments of control (Barro 1973; Ferejohn 1986). The practice of political advantage and the mitigation of agency loss with competitive elections is inherently dynamic. In this respect, Ferejohn's model involves multiple periods of an infinite horizon, to be exact. In this model an incumbent political authority can exert effort on behalf of citizens, who prefer more effort to less. It is important to note, however, that the dividends of political effort change over time and the incumbent political authority remains observant of this effort. O'Donnell (1994) posits that in competitive elections, high levels of voter awareness matter more to accountable governance than other social and economic factors. In recent times voters have also become vigilant regarding the actions and inactions of political authorities. In most countries, citizens stay informed about governance and actively register their displeasure with maladministration through demonstrations and the formation of pressure groups to shape national development in an attempt to demand accountability from political leadership.

The instrument used by the voter to assess the value of political dividend is the simple retrospective voting rule. This defines an approach whereby voters re-elect the incumbent political authority for another term if their effort exceeds a specific threshold. This is not without the voter incurring agency cost for their voting choice. Voters' expectations compared to the performance of the political authority have consequences on voting patterns. According to Sean (2012) if the dividend of effort to voters is too small, the incumbent political authority completely neglects a duty, knowing that even very high effort will not be enough to put voters' expectations over its retrospective threshold. If, however, the dividend of effort to voters is large enough, politicians exert some effort but only the minimal amount necessary to be re-elected. This effort diminishes when the dividend of effort increases, because the incumbent can work less hard and still satisfy the voters' retrospective threshold. Note, however, that the extent of agency loss can be judged relative to an alternative institutional arrangement. Persson et al (1997) show that the creation of separate institutions with powerful checks and balances can mitigate agency loss. In essence, the authors argue that where there is a separation of powers in which political actors have inherent preferences, conflicts for example between the legislature and the executive can serve as a good source of information to the voter about the possible dividend of policy-making to inform the voter's choice. 
Until recently, principal-agent analyses of the electoral nexus centred on the concept of moral hazard. The focus of this assertion was to use elections as instruments of control over politicians' behaviour, their desires and choices. However, about a decade ago scholars like Banks and Sundaram (1998) postulated the formal analysis of elections with both moral hazard and adverse selection. In support of this proposition, Fearon (1999) noted that elections not only provide an instrument with which to sanction wayward politicians, but also an instrument for selecting politicians with desirable traits or preferences. This idea of elections serving as a sanctioning and selection tool provides a more pragmatic solution to agency problems than previously thought to be predicated on moral hazard theory. The limitation therefore is that though voters face both adverse selection (selecting competent politicians) and moral hazard problems (inducing the politician's choice of the voter's preferred policy), the adverse selection dimension trumps the moral hazard in equilibrium (Sean 2012). This is because the rational behaviour by voters, coupled with their information asymmetry and limited instruments of control over politicians, can lead to the decision by politicians to neglect their own private information about socially desirable policies and pursue a populist course of action that the less-informed electorate considers beneficial (Majumdar \& Mukand 2004). However, with the proliferation of mass media and the attendant power of social media and community-based radio stations, the degree of information asymmetry is drastically minimised and thereby broadens the measure of accountability options for the voter. Studies on principal-agent models assert that public accountability in electoral democracies is inherently limited, notwithstanding the fact that the voters may exhibit imperfection in their voting choice (Fox \& Shotts 2009; Ashworth \& Bueno de Mesquita 2009). This makes the rational concept in principal-agent models useful in assessing the outer limits of public accountability that can be produced by competitive elections, principally because it indicates that the limitations of voters can be blamed only so much for an accountability crisis in governance.

\section{AGENCY COST}

Once political leaders are elected into public office they may pursue their own political agendas, thereby limiting the amount of accountability they are willing to supply. The expectation differential between principals (voters) and agents (elected leaders) may incur a deficit of political accountability in which the demands of the voter usually exceeds supply by the incumbent government. In electoral democracies, the citizens as principals of the agency theory incur two main costs. The first is the compensation cost which consists of remunerations paid to the political authorities once they are elected into public office. The second is the 
indirect cost of performances and mistakes by the agents (political authorities), which could go as high as the complete loss of huge national assets in the form of public wastage. This arises where politicians promise 'paradise on earth' during political campaigning but end up accomplishing only destruction once elected into office. One example is the cost to the United States of America in terms of both money and loss of life during the Gulf War of 1990-1991 and the subsequent invasion of Iraq in 2003 during the presidencies of George HW Bush and his son, George W Bush respectively. This is similar to the resources spent by the Obama administration in 2011 when a multi-state NATO-led alliance joined forces to intervene in the Libyan revolution to oust Gaddafi, against the expectations of some American citizens.

The incumbent political authority may exercise discretion on which policy choices to implement. This is a general mandate and legitimacy conferred on the incumbent by voters is to implement policies that are in their (i.e. the voters) interest. However, sometimes an overt or covert political agenda may override the voter's interests. This is because the politician's attempt to implement the election contract with the agent tends to make them implement ad hoc, haphazard and uncoordinated programmes that are inimical to the voter's interest. Due to the opaque nature of the election contracts, the politicians would wish to amass monetary resources to allow them to operate freely as political entrepreneurs. These resources will sometimes be used to remunerate the people who helped them win elections, using massive propaganda to convince the principals about their suitability as political agents.

The classical Burkean theory of politicians as guardians of the general interests of the principal serves as the foundation of agency cost (Burke 1999). The concept of the asymmetry of information leads to voter ignorance being exploited by political authority. Sometimes the rent-seeking ambitions of political agents lead them to engage in illegal activities such as patronage, misappropriation, corruption, tax fraud, and commissions on public contracts. An economic rent is an unearned income, meaning an excessive remuneration compared with what had to be paid, or it is a payment in excess of the opportunity cost. The theory of economic rent focuses on monopoly profits, collusion gains from oligopolistic competition, as well as rents for lobbying government to secure lucrative contracts (Tullock 2005). This mean that the nature of the political regime and its basic structures of public law affects how political agents maximise the rents. In competitive electoral democracies, the agency costs for political regimes with open access tend to be much lower than those of closed regimes. Political agents who cause excessive cost to the voters may be voted out of office. Thus, in agency theory, the voter as principal may exercise a vote of censure against the incumbent government (the agent) which incurs an agency cost that is expensive to the voter. Agency cost 
means any action or inaction on the part of the incumbent government that is inimical to the interests of the voter.

\section{CONCLUSION}

The theory of agency has been shown to be a useful concept for analysing the impact of competitive elections on the accountability of political incumbents and the implementation of their policy options. Continuous expansion of this doctrine of political accountability offers a rich field for literature in political and social science. One area of study could be a narrow focus on the effect of agency theory on parliamentary democracy and the relationship between judicial precedents on the law of agency and public accountability. The theory is better understood as an accountability model in both political, social and commercial life. Politics consists of both policy-making and policy implementation, and in their quest to win political power, politicians offer myriad promises in the form of manifestoes. Political agents package these promises as products and sell them to the voters through both direct engagement and mass media publicity. In competitive elections, once a political party or candidate (agent) is elected into power, then the products are deemed to have been bought by the voters (principals) to satisfy their utility. This utility includes the expectation of the voters that the elected political agents will formulate and implement programmes in the interest of the population.

Voters as principals rely upon these political agents to deliver public services. However, sometimes political agents pursue programmes and policies that depart from the interests of the electorates and the population as whole. This results in information asymmetries, incentive problems, and agency cost.

In the long term, a lack of symmetrical information does not pose a major challenge as the voter, or principal, has the authority to direct the work of political authorities (the agents). However, in the short term the election of bad government can only be remedied by high agency costs, as failure to fulfil electoral incentives and voter expectations may be interpreted as a breach of contract between the principal and the agent. This may be contested in court to seek the enforcement of directive principles of state policy to the benefit of citizens. This means that in a regime governed by the rule of law, the hidden actions and knowledge of the political elite in taking advantage of the voters' choice will be minimised. This reveals the fundamental limitations on accountability imposed by political institutions, apart from the capabilities of the principals to enforce performance through legitimate and legal means or to adopt a vote of censure in the next electoral cycle. The principal-agent theory of electoral democracy seems to adopt a reasonable exploration of information asymmetries and challenges in the 
achievement of electoral incentives, juxtaposed with the best that the principals can expect to attain by exercising their voting choice. The study concludes that competitive elections offer direct choice to the voter ensuring that the principle of state governance remains accountability to the voting public.

\section{-_-_- REFERENCES --_-}

Achen, C \& Bartels, L 2002, Blind retrospection: electoral responses to droughts, flu, and shark attacks, Presented at the Annual Meeting of the American Political Science Association, Boston, MA.

Adsera, A \& Boix, C 2003, 'Are you being served? Political accountability and the quality of government', The Journal of Law, Economics and Organization, vol. 19, pp. 445-482.

Aidt, T \& Margis, F 2003, 'Capital taxation and electoral accountability', Working Paper 0318, Department of Economics, University of Cambridge.

American Law Institute 2006, Restatement of the law, agency, American Law Institute, St. Paul, Min.

Ashworth, S 2012, 'Electoral accountability: recent theoretical and empirical work', Annual Review of Political Science, https://www.annualreviews.org/journal/ poliscipolisci.annualreviews.org

Ashworth, S \& Bueno de Mesquita, E 2009, 'Electoral selection, strategic challenger entry, and the incumbency advantage', Journal of Politics, vol. 70, pp. 1006-1025.

Aviva Life and Pensions UK Ltd v Strand Street Properties Ltd 2010EWCA Civ 444. Banks, J \& Sundaram, R1998, 'Optimal retention in agency problems', Journal of Economic Theory, vol. 82, pp. 293-323.

Barro, R 1973, 'The control of politicians: An economic model', Public Choice, vol. 14, pp. $19-42$.

Berle, A \& Means, G 1932, The modern corporation and private property, Macmillan, New York, NY.

Besley, T \& Burgess, R 2002, 'The political economy of government responsiveness: theory and evidence from India' Quarterly Journal of Economics, vol. 117, pp. 1415-1451.

Besley, T \& Case, A 1995b, 'Incumbent behavior: vote-seeking, tax-setting, and yardstick competition', American Economic Review, vol. 85, no. 1, pp. 25-45.

Bolton, P \& Dewatripont, M 2004, Contract Theory, MIT Press, Cambridge, MA. Bovens, M 2007, 'Analysing and assessing accountability: a conceptual framework', European Law Journal, vol. 13, pp. 447-468.

Bratton, M \& Logan, C 2014, 'From elections to accountability in Africa', Governance in Africa, vol. 1, pp. 1-12. 
Burke, E. 1999, The portable Edmund Burke, Penguin, London.

Crawford, G 2004, 'Democratic decentralization in Ghana: issues and prospects', POLIS Working Paper No. 9.

Daily, CM, Dalton, DR \& Rajagopalan, N 2003, 'Governance through ownership: centuries of practice, decades of research', Academy of Management Journal, vol. 46, no. 2, pp. 151-158.

Dixit, A, Grossman, G. \& Helpman, E 1997, ‘Common agency and coordination: general theory and application to government policy making', Journal of Political Economy, vol. 105, pp. 752-769.

Downs, A 1957, An economic theory of democracy, Harper \& Collins, New York.

Fearon, J 1999, 'Electoral accountability and the control of politicians', in A Przeworski, B Manin \& S Stokes (eds.), Democracy, accountability, and representation, Cambridge University Press, New York.

Ferejohn, J 1986, 'Incumbent performance and electoral control', Public Choice, vol. 50, pp. 5-25.

Fox, J \& Shotts, K 2009, 'Delegates or trustees? a theory of political accountability', Journal of Politics, vol. 71, pp. 1225-1237.

Ghana, 1992, Constitution of the Republic of Ghana, Tema Press, Accra.

Goetz, A \& Gaventa, J 2001, 'Bringing citizen voice and client focus into service delivery.' IDS Working Paper, No. 138, University of Sussex, Brighton.

Hammond, T \& Knott, J 1996, 'Who controls the bureaucracy? Presidential power, congressional dominance, legal constraints, and bureaucratic autonomy in a model of multi-institutional policy-making', Journal of Law, Economics, and Organization, vol. 12, no 1, pp. 119-166.

Healy, A \& Malhotra, N 2010, 'Random events, economic losses, and retrospective voting: implications for democratic competence', Quarterly Journal of Political Science vol. 5, pp. $193-208$.

Lane, J-E, 2013, 'The principal-agent approach to politics: policy implementation and public policy-making', Open Journal of Political Science, vol. 3, no.2, pp. 85-89.

Jensen, MC \& Meckling, WJ, 1976, 'Theory of the firm: managerial behavior, agency costs and ownership structure', Journal of Financial Economics, vol.3, pp. 305-60.

Kayser, MA \& Peress, M 2011, Benchmarking across borders: electoral accountability and the necessity of comparison, Unpublished manuscript.

Lenz, G 2012, Follow the leader: how voters respond to politicians' performance and policies, University of Chicago Press, Chicago.

Lupia, A \& McCubbins, M 1998, The democratic dilemma: can citizens learn what they need to know? Cambridge University Press, New York.

Majumdar, S \& Mukand, S 2004, 'Policy gambles', American Economic Review, vol. 94, pp. 1207-1222.

Moncrieffe, J 1998, 'Re-conceptualizing political accountability', International Political Science Review, vol. 19, pp. 387-406. 
Montgomerie v United Kingdom Mutual Steamship Association (1891)1 Q.B.370.

O'Donnell, G 1994, 'Delegative Democracy', Journal of Democracy, vol. 5, pp. 55-69. Persson, T, Roland. G, \& Tabellini, G 1997, 'Separation of powers and political accountability', Quarterly Journal of Economics, vol. 112.

Queen vs. Kane (1901)1 Q.B. 472.

Rasmusen, E 2006, Games and information, Blackwell, Oxford.

Rose, R, Mishler, W \& Haerpfer, C 1998, Democracy and its alternatives: understanding post-communist societies, Johns Hopkins University Press, Baltimore.

Ross, S 1973, 'The economic theory of agency: the principal's problem', American Economic Review, vol. 63, no. 2, pp. 134-139.

Sealey, LS \& Hooley, RJA 2008, Commercial law: text, cases and materials, $4^{\text {th }}$ ed, Oxford University Press, [Oxford].

Sean, G 2012, 'Accountability and principal-agent models', in Oxford Handbook of Public Accountability; forthcoming, Oxford University Press, [Oxford].

Tullock, G 2005, The rent-seeking society, Liberty Fund, Washington, DC.

Wasserman, N 2006, 'Stewards, agents, and the founder discount: executive compensation in new ventures, Academy of Management Journal, vol. 49, no. 5, pp. 960-976.

Weingast, B, \& Moran, M 1983, ‘Bureaucratic discretion or congressional control? Regulatory policy making by the federal trade commission', Journal of Political Economy, vol. 91, no. 5, pp. 765-800. 